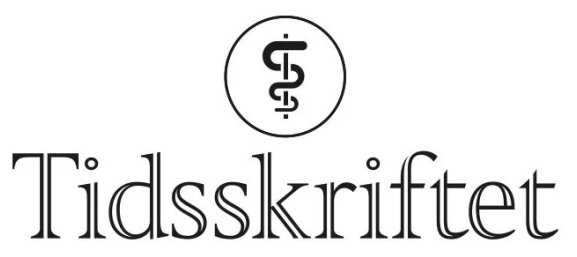

DEN NORSKE LEGEFORENING

\title{
KO. Nakken og E. Sætre svarer
}

\author{
KOMMENTAR \\ KARL O. NAKKEN \\ karln@ous-hf.no \\ Karl O. Nakken er pensjonert nevrolog.
}

\section{ERIK SATRE}

Ingen av forfatterne har oppgitt noen interessekonflikter.

Vi takker kollegene Myren-Svelstad og Fjær for interessante betraktninger rundt vårt forslag til en ny og mer presis betegnelse på legemiddelgruppen som brukes ved epilepsi, og som lenge har vært kalt antiepileptika (1). All debatt om vår begrepsbruk hilses velkommen.

Av og til er det vanskelig å finne gode norske fagtermer. De bør være presise, dekkende, og ikke minst lett anvendelige. Det siste gjør at man tidvis må inngå kompromisser.

Myren-Svelstad og Fjærs forslag om at det engelske «antiseizure medicine» på norsk bør hete anfallsforebyggende epilepsimedisin, kan nok ved første øyekast virke tiltalende. Men etter vårt skjønn er betegnelsen epilepsimedisin uheldig. Dette begrepet kan nok passere i muntlige eller populærvitenskapelige sammenhenger, men vi mener det er for upresist $\mathrm{i}$ faglige fora. Medisiner er et vidtfavnende og uspesifikt begrep og brukes blant annet også om naturpreparater. Om skolemedisinske farmaka mener vi betegnelsen legemidler bør brukes.

Da man i den internasjonale epilepsiorganisasjonen ILAE ble enige om å kvitte seg med den ukorrekte betegnelsen «antiepileptic drug» (AED), ønsket man opprinnelig å bytte til «antiseizure drug» (ASD). Man kom imidlertid fort over vær med at ASD kunne forveksles med den godt innarbeidede forkortelsen for «autism specter disorder». Man valgte derfor «antiseizure medicine» (ASM). I Norge trenger vi ikke være bundet av dette.

Vi kan være enige i at anfall på norsk er et begrep som kanskje favner noe videre enn det engelske «seizure». For å få frem at det er epileptiske anfall det dreier seg om, var vi inne på å foreslå legemidler som forebygger epileptiske anfall. Det blir imidlertid for altfor tungvint i bruk, både skriftlig og muntlig. Selv om vårt forslag om anfallsforebyggende legemidler ikke er helt optimalt, mener vi det likevel er bedre enn Myren-Svelstad og Fjærs forslag.

Everolimus anser vi ikke å høre inn under anfallsforebyggende legemidler. Det er primært et anti-tumorpreparat. 
LITTERATUR

1. Nakken KO, Sætre E. Anfallsforebyggende legemidler, ikke antiepileptika. Tidsskr Nor Legeforen 2020; 140. doi: 10.4045/tidsskr.20.0536. [CrossRef]

Publisert: 12. oktober 2020. Tidsskr Nor Legeforen. DOI: 10.4045/tidsskr.20.0747

(C) Tidsskrift for Den norske legeforening 2023. Lastet ned fra tidsskriftet.no 26. april 2023. 